\title{
OCENA SKUTECZNOŚCI INSTRUMENTÓW PRAWNYCH W ZAKRESIE GOSPODAROWANIA ODPADAMI STOSOWANYCH PRZEZ FUNKCJONARIUSZY STRAŻY GMINNYCH (MIEJSKICH) NA PRZYKEADZIE DZIAŁALNOŚCI STRAŻY GMINNEJ W KĘSOWIE ORAZ STRAŻY MIEJSKIEJ W BYDGOSZCZY
}

\section{ASSESSMENT OF EFFECTIVENESS OF STATUTORY INSTRUMENTS IN WASTE MANAGEMENT APPLIED BY COMMUNE GUARDS (ON THE EXAMPLE OF ACTIVITIES OF THE COMMUNE GUARD IN KĘSOWO AND BYDGOSZCZ)}

\section{STRESZCZENIE}

Reforma systemu postępowania z odpadami komunalnymi obciążyła gminy odpowiedzialnością za rozwiązanie problemu odpadów. Zadaniem gminy jest między innymi nadzór nad wykonywaniem obo-

* Doktor nauk prawnych, Bydgoska Szkoła Wyższa. 
wiązków obciążających mieszkańców. Zadanie to jest wykonywane głównie przez straże gminne. Artykuł analizuje praktyczne aspekty i efekty prowadzenia kontroli przez funkcjonariuszy straży gminnych w wybranych miejscowościach województwa kujawsko-pomorskiego.

\section{Słowa kluczowe}

Gospodarowanie odpadami; odpady komunalne; straże gminne (miejskie); odpowiedzialność administracyjna.

\section{ABSTRACT}

The reform of the system of municipal waste management held communes responsible for the problem of waste. The task of commune administrative bodies is, among other things, to supervise the performance of duties imposed on residents of a commune. This task is mainly performed by commune guards. The article analyses practical aspects and effects of inspections conducted by commune guards in chosen towns of the kujawsko-pomorskie voivodeship.

\section{Keywords}

Waste management; municipal waste; municipal police; administrative responsibility.

\section{WSTĘP}

Ustawodawca dokonując zmiany systemowej w zakresie gospodarowania odpadami, scedował realizację wymogów prawnych w tym zakresie na gminy. Organy tych jednostek w praktyce częściowe wykonywanie tych obowiązków zleciły strażom gminnym (miejskim). Jest oczywiste, że wykonywanie zadań powinno się odbywać przy użyciu odpowiednich narzędzi, których skuteczność nie powinna budzić wątpliwości, a dostępne instrumenty prawne powinny być na tyle skuteczne, by nie dochodziło do naruszania czy pomijania obowiązujących przepisów. Założono więc podjęcie badań, których głównym celem będzie ocena skuteczności stosowania tych instrumentów 
oraz zapewniania przestrzegania obowiązujących norm prawnych odnoszących się do gospodarowania odpadami przez formację, która realizuje cześć zadań w bezpośrednim kontakcie z podmiotami naruszającymi przepisy w tym zakresie. Opracowanie będzie próbą odpowiedzi na następujące pytania badawcze: 1. Czy reforma zobowiązująca gminy do realizacji zadania w zakresie gospodarowania odpadami jest skuteczna i jak jest postrzegane to rozwiązanie z punktu widzenia funkcjonariuszy straży gminnych (miejskich)? 2. Jakie są największe problemy w zakresie egzekucji przepisów prawa? 3. Które z problemów są najbardziej uciążliwe podczas interwencji związanej $\mathrm{z}$ łamaniem przepisów „odpadowych”? 4. Na ile problemy proceduralne wpływają na prawidłowe wykonywanie obowiązków przez funkcjonariuszy straży? Dodatkowo badanie ma wskazać na najczęstsze uchybienia posiadaczy odpadów oraz dać odpowiedź na pytanie - czy funkcjonariusze badanych jednostek zostali odpowiednio przeszkoleni po reformie systemu gospodarki odpadami?

Najważniejszymi narzędziami prowadzenia badań była analiza aktualnego stanu prawnego w zakresie gospodarowania odpadami i funkcjonowania straży oraz ankieta kierowana do funkcjonariuszy badanych formacji w Kęsowie i Bydgoszczy. Treść przedmiotowa analizowanego problemu ograniczona została do „odpadów komunalnych”.

\section{USTALENIE PODSTAW PRAWNYCH GOSPODAROWANIA ODPADAMI W GMINACH I DEFINICJE GŁÓWNYCH POJĘĆ}

Najważniejszymi aktami prawnymi w zakresie gospodarowania odpadami w Polsce są: Ustawa z dnia 14 grudnia $2012 \mathrm{r}$. o odpadach ${ }^{1}$ oraz Ustawa z dnia 13 września 1996 r. o utrzyma-

1 Dz.U. z 2013 r. poz. 21 i n. 
niu czystości i porządku w gminach ${ }^{2}$. W treści art. 3 ust. 1 pkt. 6 pierwszego ze wskazanych aktów ustalono definicję legalną "odpadów”, zgodnie z którą odpadem jest „każda substancja lub przedmiot, których posiadacz pozbywa się, zamierza się pozbyć lub do których pozbycia jest obowiązany"3. Ze względu na problem badawczy istotna jest także definicja „odpadów komunalnych”, którymi są „odpady powstające w gospodarstwach domowych, z wyłączeniem pojazdów wycofanych z eksploatacji, a także odpady niezawierające odpadów niebezpiecznych pochodzące od innych wytwórców odpadów, które ze względu na swój charakter lub skład są podobne do odpadów powstających w gospodarstwach domowych $[\ldots]$ ". .

Do systemu aktów objętych zakresem zainteresowania przeprowadzonych badań oraz niniejszego opracowania należy także włączyć Ustawę z dnia 8 marca 1990 r. o samorządzie gminny ${ }^{5}$, która ustala zakres obowiązków gmin odnoszących się do zaspokojenia zbiorowych potrzeb wspólnoty, którymi są „zadania własne ${ }^{6}$ obejmujące sprawy w zakresie „[...] utrzymania czystości i porządku [...] i unieszkodliwiania odpadów komunalnych [...]"'

W zakresie zadań wykonywanych przez gminy istotne są przepisy Ustawy o utrzymaniu czystości i porządku w gminach, która oprócz unormowania „warunków wykonywania działalności w zakresie odbierania odpadów komunalnych od właścicieli nieruchomości i zagospodarowania tych odpadów"8 ustala szereg obowiązków nałożonych na gminę w zakresie gospoda-

2 T. j. Dz.U. z 2013 r. poz. 1399 z późn. zm.

3 Co do wątpliwości, jakie budzą te definicje, zob. m.in. J. Jerzmański, Kontrowersje wokót prawnego pojęcia odpadów, „Ochrona środowiska. Prawo i Polityka” 1996, nr 1; W. Radecki w komentarzach do powołanych przepisów. W. Radecki, Ustawa o utrzymaniu czystości i porządku w gminach. Komentarz, Warszawa 2012; W. Radecki, Ustawa o odpadach. Komentarz, Warszawa 2013.

4 Art. 3 ust. 1 pkt 7 Ustawy z dnia 14 grudnia 2012 r. o odpadach.

5 T.j. Dz.U. z 2014 r. poz. 379; dalej cyt.: Ustawa o samorządzie gminnym.

6 Zob. E. Ochendowski., Prawo administracyjne, Toruń 2009, s. 310 i n.

7 Art. 7 ust. 1 pkt 3 Ustawy o samorządzie gminnym.

8 Art. 1 pkt 2 Ustawy z dnia 13 września 1996 r. o utrzymaniu czystości i porządku w gminach (t. j. Dz.U. z 2013 r. poz. 21 z późn. zm.). 
rowania odpadami. Należy dodać, że obowiązki te kierowane są do wszystkich gmin w Polsce bez względu na ich status, czyli jednakowe przepisy dotyczą gmin zarówno „wiejskich” jak $\mathrm{i}$ „miejskich".

Nowy system w zakresie gospodarowania odpadami oparty jest na tzw. „władztwie gminy” nad odpadami ${ }^{10}$. W skrócie oznacza to, że gmina w całości przejmuje odpowiedzialność za odpady, a finansowanie działań dotyczących gospodarowania odpadami komunalnymi powinno być realizowane z obowiązkowych opłat wnoszonych przez mieszkańców gminy.

\section{PRAWNE PODSTAWY I INSTRUMENTY WYKONYWANIA ZADAŃ STRAŻY GMINNYCH ${ }^{11}$ (MIEJSKICH) W ZAKRESIE GOSPODAROWANIA ODPADAMI}

Straże gminne oraz miejskie funkcjonują w oparciu o Ustawę z dnia 29 sierpnia 1997 r. o strażach gminnych ${ }^{12}$. „Straż gminna” jest „samorządowa umundurowaną formacją"13 tworzoną dla „ochrony porządku publicznego". Zgodnie z art. 2 ust. 3 omawianego aktu w gminach, którego organem wykonawczym jest burmistrz lub prezydent miasta formacja nosi nazwę „straż miejska”. Zgodnie z art. 6 „straż jest jednostką organizacyjną gminy". Przepis ten stanowi podstawę do re-

9 Art. 15 ust. 2 Ustawy o samorządzie gminnym stanowi: „Jeżeli siedziba rady gminy znajduje się $\mathrm{w}$ mieście położonym na terytorium tej gminy, rada nosi nazwę rady miejskiej".

10 Zob. m.in. Z. Bukowski, Zadania jednostek samorzadu terytorialnego, „Recykling” 2013, nr 12, s.16-18; Prawne i organizacyjne obowiąki gmin w postępowaniu z odpadami komunalnymi, red. M. Górski, K. Nowacki, Wrocław 2012 (w szczególności rozdz. 3); M. Górski, Nowy system zarządzania odpadami komunalnymi?, „Przegląd Komunalny” 2010, nr 12, s. 40-41; M. Górski Odpowiedzialność prawna gmin, „Przegląd Komunalny” 2013, nr 9, s. 18-21.

11 Więcej na temat interpretacji przepisów prawnych zawartych w Ustawie o strażach gminnych zob. E. Gruza, D. Żebrowska, Strá் Gminna (Miejska). Komentarz do przepisów, Toruń 1996.

12 T.j. Dz.U. z 2014 r. poz. 486; dalej cyt.: Ustawa o strażach gminnych.

13 Art. 1 Ustawy o strażach gminnych. 
alizacji przez tę formację zadań nakładanych na gminę. Poza tym art. 10 ust. 1 ustawy stanowi, że straż wykonuje zadania w zakresie „ochrony porządku publicznego wynikające z ustaw i aktów prawa miejscowego". Daje to podstawę do wykonywania całego wachlarza obowiązków. Jednak należy podkreślić, że nie chodzi tu o jakiekolwiek obowiązki ale jedynie te, które są prawnie wskazywane $\mathrm{w}$ aktach normatywnych i mieszczą się w zakresie „ochrony porządku publicznego”. Zatem dla przykładu budzi wątpliwości wykonywanie zadań wskazanych w aktach planistycznych niebędących „aktami prawa miejscowego”, które - zgodnie ze wskazanym przepisem - nie powinny być wykonywane przez straż miejską. Badając dalej Ustawę o strażach gminnych, zauważyć należy, że w art. 11 zawarty jest katalog zadań przydzielonych straży gminnej przez ustawodawcę. Brakuje w nim bezpośredniego wskazania na „straż gminną” jako formację wykonującą zadania w zakresie „gospodarowania odpadami". Jednak wykaz zadań ma charakter jedynie przykładowy, co oznacza, że nie można go traktować jak katalogu zamkniętego. Z drugiej strony brak odpowiedniego wykonywania obowiązków związanych z „gospodarowaniem odpadami” przez zobowiązane do tego podmioty trzeba potraktować jako „miejscowe zagrożenie” (np. w dziedzinie ochrony środowiska) i wtedy podstawą prawną do wszelkich działań funkcjonariuszy w tym zakresie jest art. 11 ust. 1 pkt. 3. Poza tym „straż spełnia służebną rolę wobec społeczności lokalnej", a rola ta zobowiązuje funkcjonariuszy do wykonywania zadań na rzecz tej społeczności, nie wyłączając spraw związanych zagospodarowaniem odpadami.

Katalog instrumentów prawnych, jakimi dysponują straże gminne (miejskie) w zakresie gospodarowania odpadami, jest przede wszystkim związany z rodzajem popełnionego przestępstwa lub wykroczenia. Główne narzędzia egzekucji obowiązków wykorzystywane przez strażników miejskich wynikają z ustaw materialnych na czele z Ustawą z dnia 20 maja 1971 r. Kodeks wykroczeń $^{14}$, w której ustawodawca wskazał kary, środki karne 
i zasady ich wymiaru ${ }^{15}$. Z punktu widzenia wymiaru kar istotny jest także art. 10 Ustawy z dnia 13 września 1996 r. o utrzymaniu czystości i porządku w gminach (wskazujący karę aresztu i karę grzywny). Z kolei Ustawa o odpadach wprowadza kary w zakresie przedmiotowym (karę aresztu lub grzywny) za termiczne przekształcanie odpadów poza spalarnią odpadów lub współspalarnią odpadów (art. 191). Egzekucja tych kar odbywać się może na zasadach ogólnych wynikających z Ustawy z dnia 17 czerwca 1966 r. o postępowaniu egzekucyjnym $\mathrm{w}$ administracji ${ }^{16} \mathrm{z}$ wcześniejszym zastosowaniem upomnienia (art. 15) jako środka zagrożenia karą administracyjną.

W praktyce do najczęściej wykorzystywanych instrumentów prawnych przy niewywiązywaniu się z obowiązków w zakresie właściwego gospodarowania odpadami komunalnymi należy zaliczyć kary grzywny lub - w sytuacjach odmowy przyjęcia kary pieniężnej - skierowanie wniosku do sądu powszechnego.

\section{WERYFIKACJA REALIZACJI ZADAŃ W ZAKRESIE GOSPODARKI ODPADAMI PRZEZ STRAŻ GMINNA W KĘSOWIE ORAZ STRAŻ MIEJSKĄ W BYDGOSZCZY NA TLE DZIAŁAŃ FAKTYCZNYCH}

Straż Gminna w Kęsowie została powołana przez Radę Gminy w Kęsowie po zaciągnięciu opinii Komendanta Wojewódzkiego Policji w Bydgoszczy w dniu 1 maja 2007 r. Siedzibą tej straży jest miejscowość Kęsowo ${ }^{17}$, znajdująca się w powiecie tucholskim w województwie kujawsko-pomorskim. Przez pięć lat straż w Kęsowie działała w obszarze administracyjnym gminy Kęsowo, zaś - od zawarcia z przyległą gminą porozumienia

15 Zob. art. 18 i n. k.w.

16 T.j. z 2014 r. poz. 379 i n.

17 Zob. § 1 i § 2 oraz pkt. 1 załącznika do Uchwały Nr VI/30/2007 Rady Gminy w Kęsowie z dnia 15 marca 2007 r. w sprawie powołania Straży Gminnej, dostępna na: http://www.kesowo.asi.pl/pls/kesowo/dokumenty/ F27697/30.pdf [dostęp: 6.11.2014 r.] 
międzygminnego - poszerzyła obszar swojego działania także o teren administracyjny gminy Gostycyn. Z kolei Straż Miejska w Bydgoszczy powstała 24 lata temu w celu zapewnienia większej skuteczności działań w zakresie bezpieczeństwa obywateli miasta. Do katalogu działań faktycznych funkcjonariuszy dołączono zadania związane z weryfikacją obowiązków związanych z gospodarowaniem odpadami przez właścicieli posesji.

Należy przypuszczać, że specyfika działań w mieście jest inna od realizacji tego obowiązku na wsi. Przyczyną może być (dla przykładu) zwarta miejska zabudowa powodująca znaczną kumulację odpadów w miastach w stosunku do rozproszonej zabudowy wiejskiej. Dlatego można się spodziewać, że niektóre problemy występujące w zakresie realizacji obowiązku „śmieciowego" mogą być inne w mieście niż na wsi. Przeprowadzone badania skoncentrowane były jedynie na tych funkcjonariuszach obu straży, którzy faktycznie i czynnie zaangażowani są w pracę związaną z egzekwowaniem obowiązków w zakresie gospodarki odpadowej na podległym terenie. Próba badawcza wytypowana do badania obejmowała zarówno w Kęsowie, jak i w Bydgoszczy 100\% funkcjonariuszy skierowanych do pracy w terenie. Należy uznać, że opinia tych osób jest szczególnie cenna dla uzyskania rzeczywistego obrazu stanu gospodarowania odpadami komunalnymi.

Pierwszy badany problem pokazuje ogólną ocenę skuteczności reformy w zakresie gospodarowania odpadami komunalnymi. Ocena ta przedstawiona jest na wykresie nr 1, gdzie dostrzec można, że aż 50\% strażników z Kęsowa uznało reformę jako nieskuteczną. W Bydgoszczy ten odsetek kształtuje się na poziomie $36,4 \%$ funkcjonariuszy. Ocena ta zastanawia, także w kontekście następnego pytania badawczego, ale być może związana była z faktem prowadzenia badań w początkowym okresie funkcjonowania nowych systemów, gdy ich zasady nie w pełni jeszcze były poznane przez adresatów obowiązków. 
Wykres nr 1. Ogólna ocena skuteczności reformy w zakresie gospodarowania odpadami komunalnymi

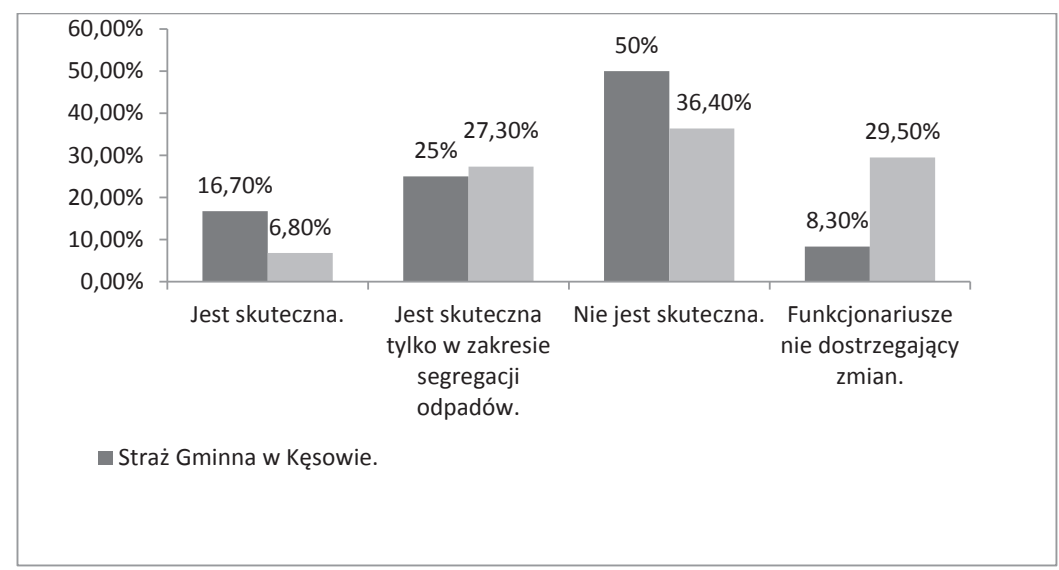

Źródło: opracowanie własne na podstawie badań przeprowadzonych wśród funkcjonariuszy Straży Gminnej w Kęsowie oraz Straży Miejskiej w Bydgoszczy od dnia 5 listopada 2014 r. do 15 stycznia 2015 r.

Z kolei pytanie drugie i oparty na nim wykres nr 2 poświęcone zostały ocenie samego systemu, którego celem było przekazanie odpowiedzialności za odpady gminie, czego efektem jest egzekucja obowiązków w tym zakresie przez strażników gminnych i miejskich. Ogólnie rozwiązanie to zarówno w Kęsowie, jak i w Bydgoszczy ocenione zostało w około 40\% pozytywnie, za wyjątkiem narzędzi prawnych, jakimi dysponują organy gminy do realizacji tego zadania. W związku z tym w obu jednostkach uznano, że należy postulować zmianę niektórych przepisów prawnych dotyczących tych właśnie kwestii. W Kęsowie taką potrzebę dostrzega $1 / 3$ badanych, w Bydgoszczy nieco ponad $40 \%$ ankietowanych. 
Wykres nr 2. Ocena systemu przejęcia odpowiedzialności za odpady przez gminę

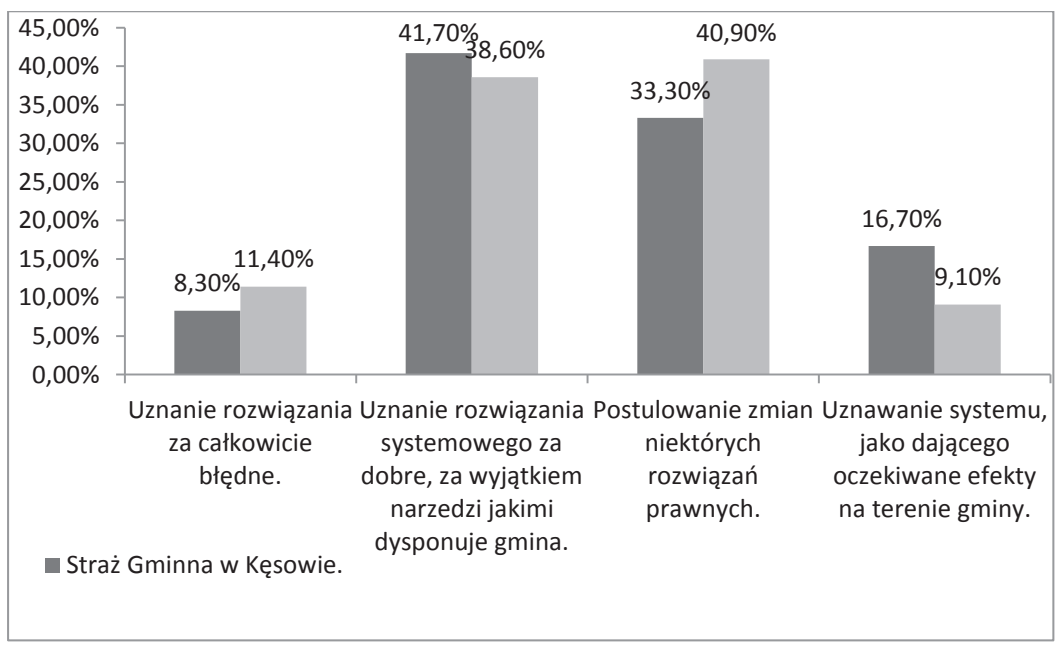

Źródło: opracowanie własne na podstawie badań przeprowadzonych wśród funkcjonariuszy Straży Gminnej w Kęsowie oraz Straży Miejskiej w Bydgoszczy od 5 listopada 2014 r. do 15 stycznia 2015 r.

Następny problem (wykres nr 3) obejmował ocenę prawidłowości rozwiązania, jakim jest przydzielenie realizacji wykonywanych zadań w zakresie odpadów komunalnych funkcjonariuszom straży. Tu pewnym zaskoczeniem jest, że zarówno funkcjonariusze z Kęsowa, jak i z Bydgoszczy nie dostrzegali potrzeby realizacji tego zadania $\mathrm{w}$ patrolach $\mathrm{z}$ Policją, a tylko 13,6\% strażników z Bydgoszczy przydzielenie tego zadania strażnikom ocenia negatywnie. Co ciekawe, nie tylko na wsi (aż 75\%), ale i w mieście (47,7\%) strażnicy dostrzegają potrzebę realizacji tego zadania przy współudziale pracowników organu gminy. 
Wykres nr 3. Ocena prawidłowości rozwiązania w postaci przydzielenia realizacji wykonywanych zadań w zakresie gospodarowania odpadami funkcjonariuszom straży gminnej/ /miejskiej

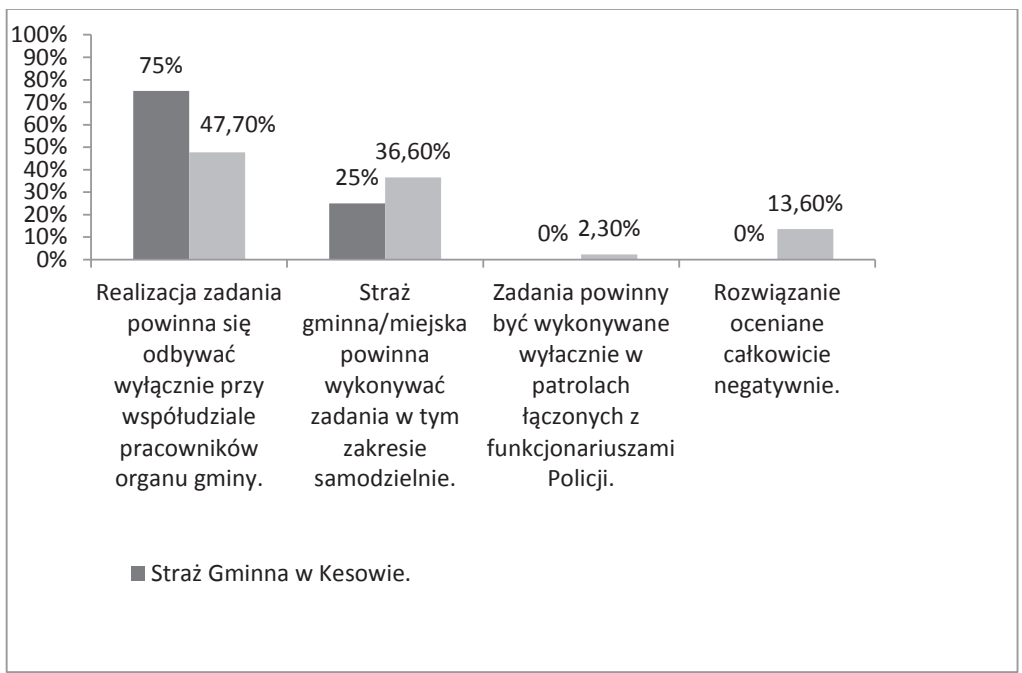

Źródło: opracowanie własne na podstawie badań przeprowadzonych wśród funkcjonariuszy Straży Gminnej w Kęsowie oraz Straży Miejskiej w Bydgoszczy od 5 listopada 2014 r. do 15 stycznia 2015 r.

Dalsza ocena rewolucji w gospodarce odpadowej skoncentrowana była na katalogu instrumentów prawnych dostępnych i wykorzystywanych dla prawidłowej egzekucji obowiązków. Obraz opinii w tym zakresie przedstawiony jest na wykresie nr 4, z którego wynika, że najwięcej kęsowskich strażników $(41,7 \%)$ uznaje brak możliwości stosowania istniejącego katalogu ze względu na niespójności lub luki w przepisach. Z kolei 36,4\% strażników bydgoskich twierdzi, iż katalog istniejących instrumentów egzekucyjnych powinien być rozszerzony. Z dostępnego w przepisach prawa katalogu kar i środków karnych w obu jednostkach uznano za najbardziej skuteczną karę grzywny (zob. wykres nr 5). Interesujące, że (także w obu jednostkach) $1 / 4$ strażników stwierdziła, że wystarczająco skutecznym środkiem jest samo zagrożenie karą i daje ono oczekiwane rezultaty w postaci wykonywania obowiązku ciążącego na podmiocie. 
Z kolei w zakresie samej egzekucji przepisów prawnych zdania strażników są podzielone (zob. wykres nr 6). W Bydgoszczy uznano, że największym problemem są niewystarczające instrumenty prawne w zakresie egzekucji (47,7\%), a w Kęsowie największy odsetek badanych nie dostrzega problemów w tym zakresie $(41,7 \%)$, natomiast - jeśli wskazują ten problem - to zasadniczo odnosi się on do niewystarczającej ściągalności nakładanych kar. Tego zdania jest $1 / 3$ badanych strażników z Kęsowa.

Wykres nr 4. Ocena katalogu instrumentów prawnych w zakresie egzekucji obowiązków

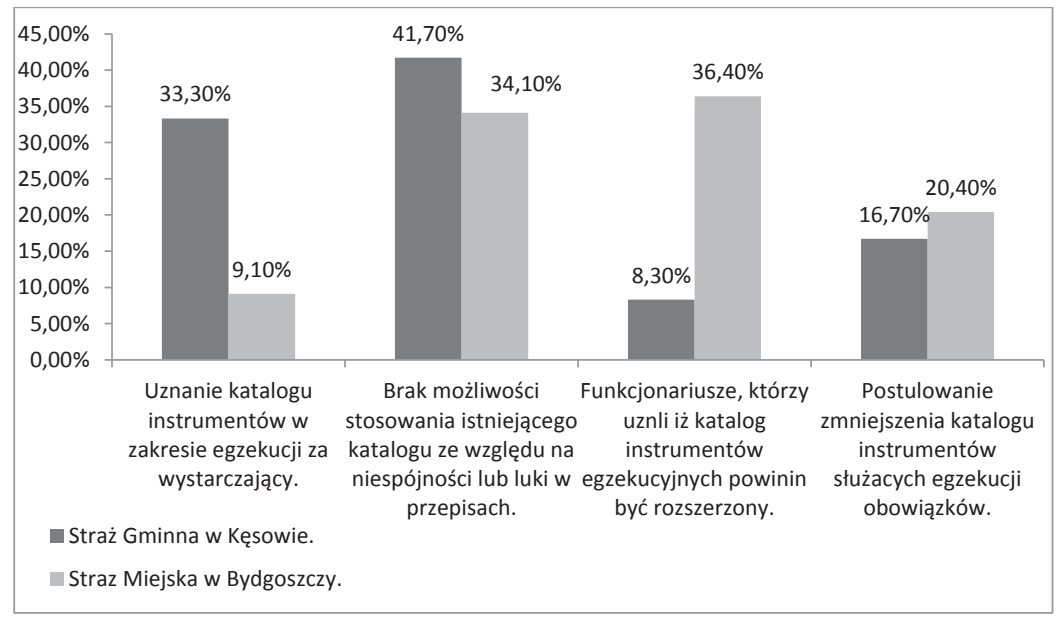

Źródło: opracowanie własne na podstawie badań przeprowadzonych wśród funkcjonariuszy Straży Gminnej w Kęsowie oraz Straży Miejskiej w Bydgoszczy od 5 listopada 2014 r. do 15 stycznia 2015 r. 
Wykres nr 5. Wskazanie najskuteczniejszego instrumentu prawnego kierowanego do podmiotów przy egzekwowaniu obowiązków w zakresie gospodarowania odpadami komunalnymi

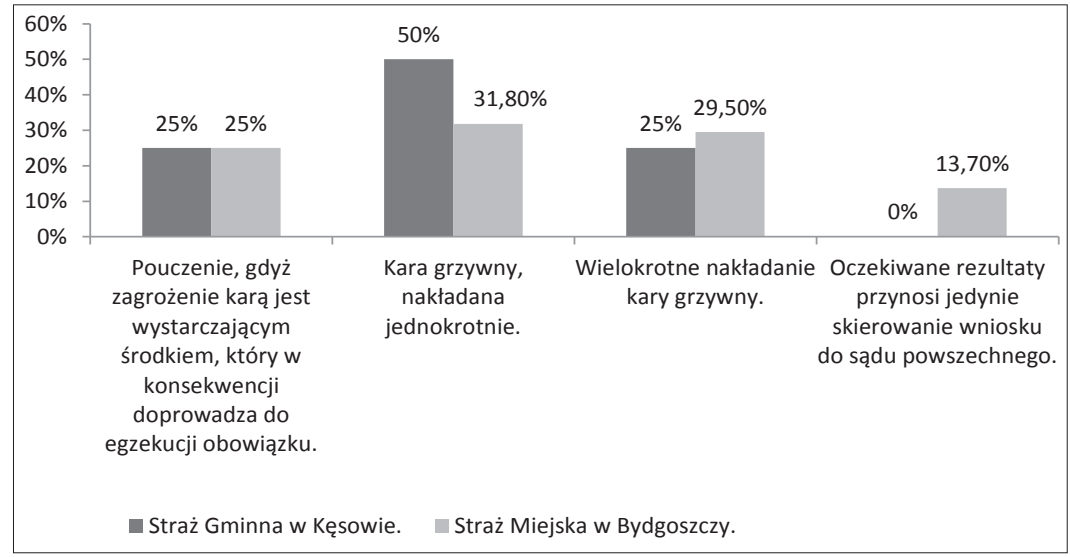

Źródło: opracowanie własne na podstawie badań przeprowadzonych wśród funkcjonariuszy Straży Gminnej w Kęsowie oraz Straży Miejskiej w Bydgoszczy od 5 listopada 2014 r. do 15 stycznia 2015 r.

Wykres nr 6. Największe problemy dostrzegane w zakresie egzekucji przepisów prawa na płaszczyźnie gospodarowania odpadami napotykane przy realizacji zadań w terenie

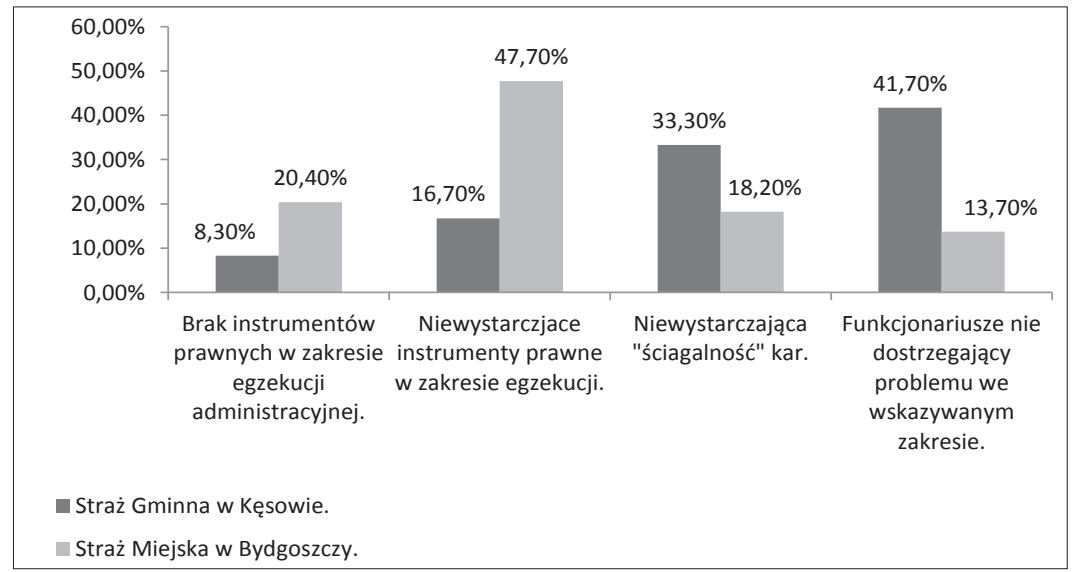

Źródło: opracowanie własne na podstawie badań przeprowadzonych wśród funkcjonariuszy Straży Gminnej w Kęsowie oraz Straży Miejskiej w Bydgoszczy od 5 listopada 2014 r. do 15 stycznia 2015 r. 
Badanie praktyki wykonywania obowiązku w zakresie gospodarowania odpadami komunalnymi zawiera także wskazanie przez strażników najbardziej uciążliwego problemu podczas interwencji. Z badań przedstawionych na wykresie nr 7 wynika, że te problemy są inne na wsi niż w mieście. Połowa badanych w Kęsowie za największy problem uznała brak możliwości ustalenia właściciela odpadów, natomiast w Bydgoszczy najbardziej problematyczne jest porzucanie lub pozostawianie odpadów w miejscach do tego nieprzeznaczonych.

Wykres nr 7. Wskazanie najbardziej uciążliwego problemu podczas interwencji związanych z odpadami

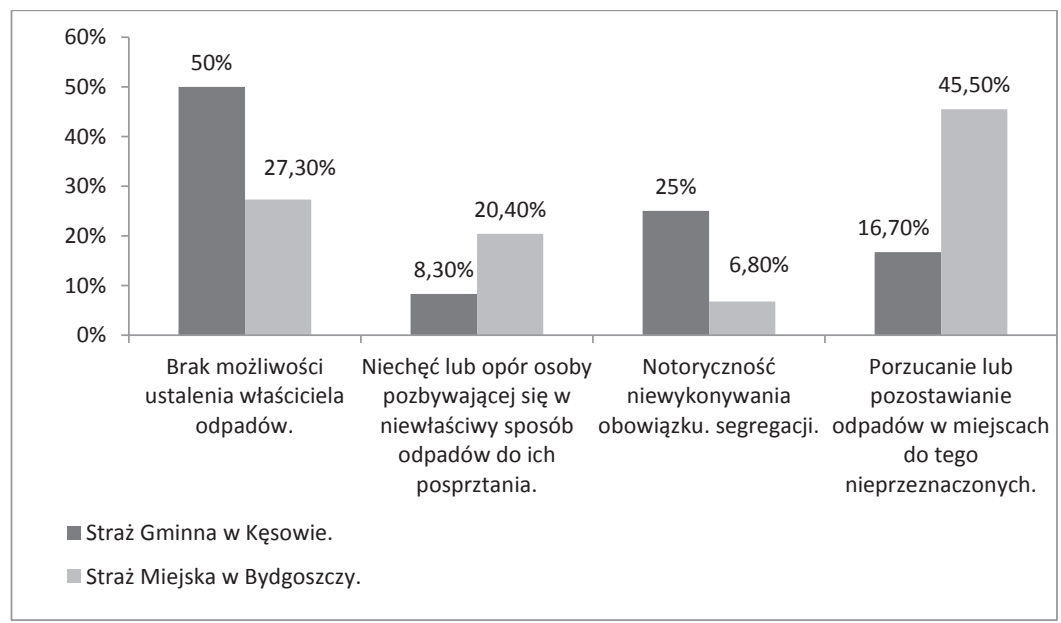

Źródło: opracowanie własne na podstawie badań przeprowadzonych wśród funkcjonariuszy Straży Gminnej w Kęsowie oraz Straży Miejskiej w Bydgoszczy od 5 listopada 2014 r. do 15 stycznia 2015 r.

Jedno z końcowych pytań badawczych związane było z zadaniami natury proceduralnej. Wykres $\mathrm{nr} 8$ wskazuje najtrudniejsze problemy w procesie wykonywania obowiązków przez funkcjonariuszy. Ich zdaniem najbardziej problematyczna jest niejasna dokumentacja w zakresie gospodarowania odpadami. W obu jednostkach problem ten dostrzega największa liczba badanych (w Kęsowie aż 58,4\% badanych). Natomiast 1/4 strażników z Bydgoszczy i 1/3 z Kęsowa jako największy problem widzi opór przedstawicieli innych organów właściwych do realizacji 
zadań w zakresie ochrony środowiska przy współudziale w rozwiązywaniu problemów w zakresie gospodarowania odpadami komunalnymi.

Wykres nr 8. Wskazanie przez funkcjonariuszy najtrudniejszych problemów proceduralnych przy wykonywaniu swoich obowiązków w zakresie gospodarki odpadowej

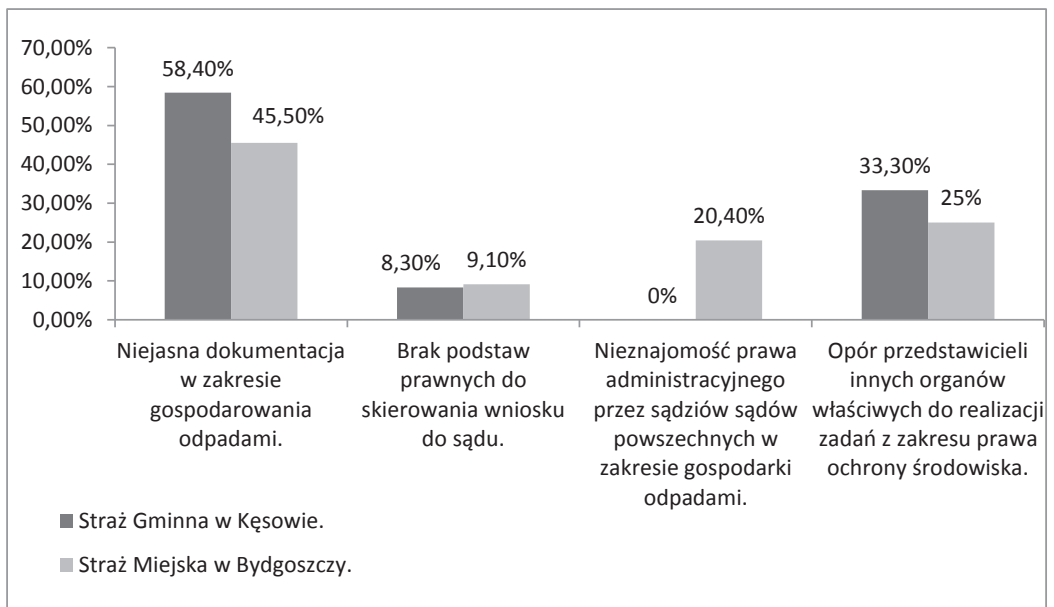

Źródło: opracowanie własne na podstawie badań przeprowadzonych wśród funkcjonariuszy Straży Gminnej w Kęsowie oraz Straży Miejskiej w Bydgoszczy od 5 listopada 2014 r. do 15 stycznia 2015 r.

Praktyka realizacji zadań w obu badanych gminach pokazała także, że największym uchybieniem samych posiadaczy odpadów jest ich porzucanie w lesie lub na pustych działkach (wykres nr 9). Reforma gospodarki odpadowej i scedowanie jej wykonywania na gminy miało zapobiegać patologiom w tym zakresie. Niestety należy stwierdzić, że wiele jej elementów jest niedoskonałych także po reformie. 
Wykres nr 9. Uchybienie posiadaczy odpadów uznawane za najbardziej problematyczne

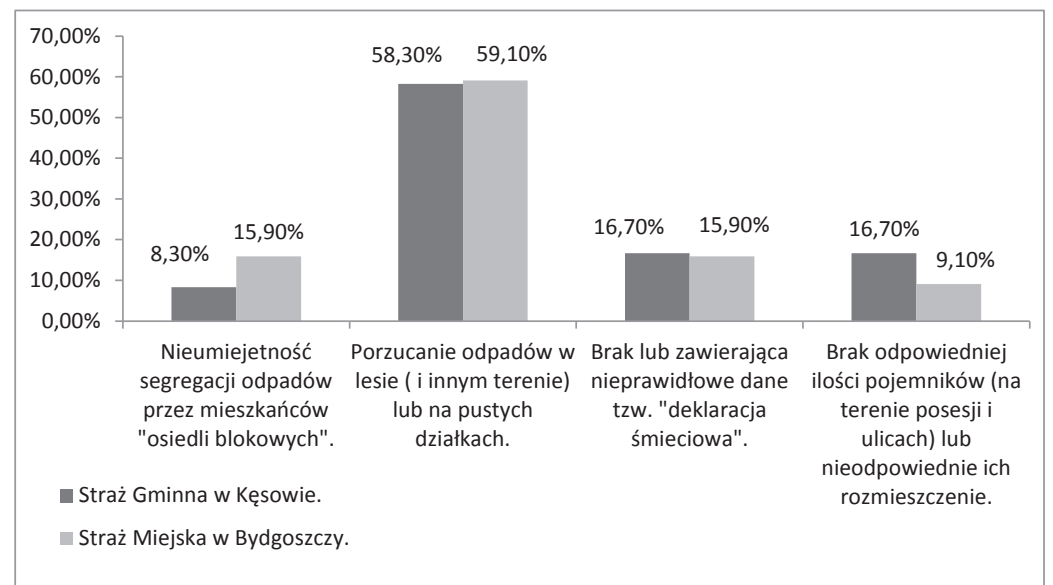

Źródło: opracowanie własne na podstawie badań przeprowadzonych wśród funkcjonariuszy Straży Gminnej w Kęsowie oraz Straży Miejskiej w Bydgoszczy od 5 listopada 2014 r. do 15 stycznia 2015 r.

Reforma w założeniach miała skutkować podniesieniem odsetka segregowanych odpadów oraz zapobiegać ich porzucaniu. Niestety same przepisy prawne przez półtora roku ich obowiązywania budziły wiele wątpliwości w praktyce ich realizowania. Dlatego po raz kolejny ${ }^{18}$ postanowiono je poprawić. Nieco zmienione normy weszły w życie już po przeprowadzeniu niniejszych badań, czyli od 1 lutego 2015 r. ${ }^{19}$ Ciągłe zmiany przepisów prawnych nie budują zaufania do organów władzy publicznej. Jednak nie to jest podstawowym problem obecnego stanu, gdyż to nie władza publiczna stanowiąca prawo jest zmuszona do bezpośredniej konfrontacji z podmiotami łamiącymi przepisy prawne. Realizacja tego zadania należy do władzy wy-

18 Ustawa była także zmieniana wcześniej, jeszcze przed uruchomieniem nowych systemów, zob. Ustawę z dnia 25 stycznia 2013 r. o zmianie Ustawy o utrzymaniu czystości i porządku w gminach oraz niektórych innych ustaw (Dz.U. z 2013 r., poz. 228).

19 Ustawa z dnia 28 listopada 2014 r. o zmianie Ustawy o utrzymaniu czystości i porządku w gminach oraz niektórych innych ustaw (Dz.U. z 2015 r., poz. 87). 
konawczej, czyli w badanym zakresie do wójtów, burmistrzów i prezydentów miast oraz, faktycznie wykonujących w ich imieniu to zadanie, pracowników gminy lub (tak jak w badanym przypadku) funkcjonariuszy straży gminnych lub miejskich. Przy ciągłej zmianie przepisów prawnych trzeba być doskonale zorientowanym w ich zakresie i bezustannie się dokształcać. W obu badanych strażach pracownicy deklarują różne formy nauki przepisów w zakresie gospodarowania odpadami, począwszy od samokształcenia (50\% badanych w Kęsowie i 31,8\% w Bydgoszczy) do szkoleń przeprowadzonych przez przełożonego (wykres nr $10 \mathrm{~A}$ i nr $10 \mathrm{~B}$ ).

Wykres nr 10 A. Uczestniczenie w szkoleniach funkcjonariuszy z Kęsowa

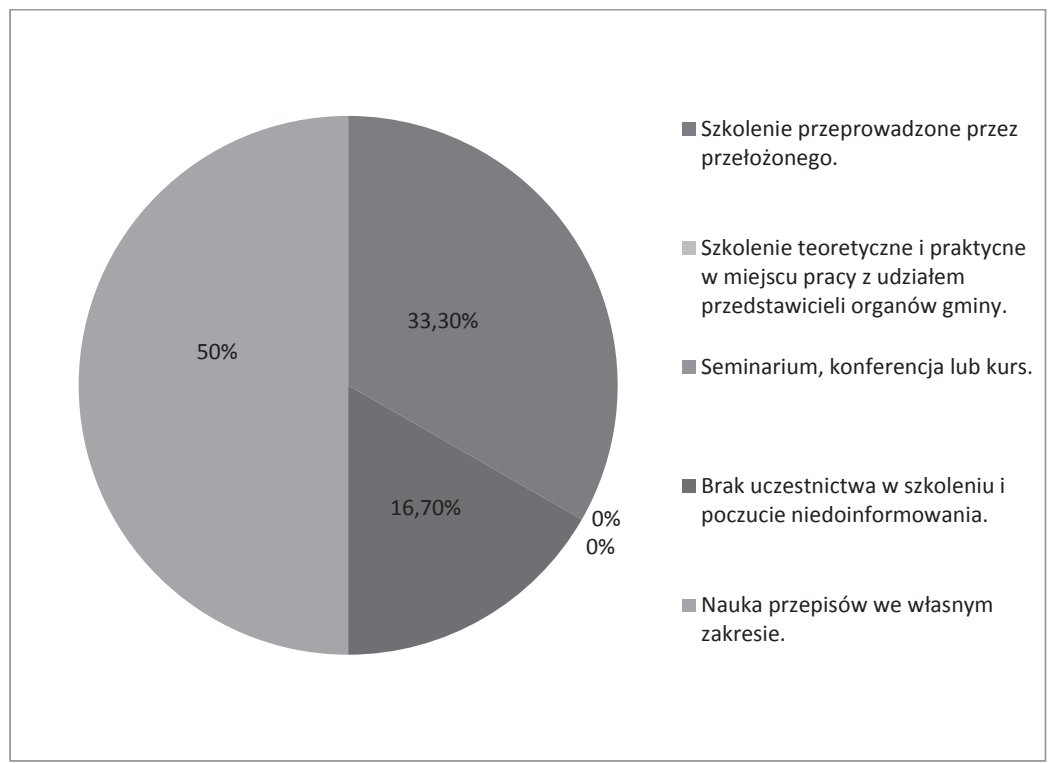

Źródło: opracowanie własne na podstawie badań przeprowadzonych wśród funkcjonariuszy Straży Gminnej w Kęsowie oraz Straży Miejskiej w Bydgoszczy od 5 listopada 2014 r. do 15 stycznia 2015 r. 
Wykres nr 10 B. Uczestniczenie w szkoleniach funkcjonariuszy z Bydgoszczy

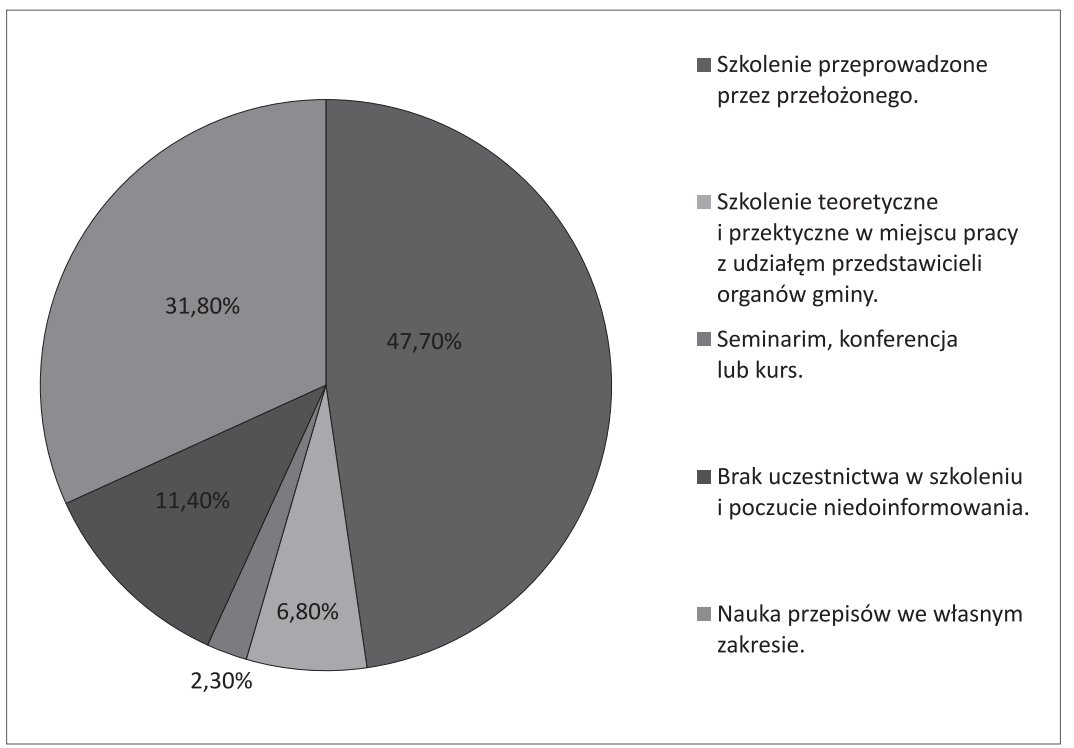

Źródło: opracowanie własne na podstawie badań przeprowadzonych wśród funkcjonariuszy Straży Gminnej w Kęsowie oraz Straży Miejskiej w Bydgoszczy od 5 listopada 2014 r. do 15 stycznia 2015 r.

\section{PODSUMOWANIE}

Przeprowadzone badania i uzyskane na ich podsatwie wyniki potwierdziły, jak się wydaje, kilka probremów, wciąż nie do końca (chyba?) uświadamianych przez ustawodawcę. Po pierwsze należy podkreślić, że nawet dość zasadnicza zmiana przepisów i budowanych $\mathrm{w}$ oparciu o nie systemów postępowania nie jest sposobem na automatyczną zmianę stosunków społecznych, które przepisy te mają regulować a także automatyczne uzyskanie zakładanych efektów. Wprowadzane zmiany muszą być bowiem dobrze przemyślane, prawidłowo skonstruowane i następnie skutecznie egzekwowane. Poza tym, dokonywane częste zmiany nowej regulacji pokazują, że nie została ona skonstruowana do końca poprawnie, co podkreślają praktycy, którzy są zobowiązani te przepisy stosować. 
Po drugie należy wskazać, że kwestia skutecznej egzekucji wprowadzonych wymagań ma podstawowe znaczenie dla zapewnienia skuteczności całej regulacji. Praktyka jednak pokazuje, że to zagadnienie nie zostało w reformie systemów postępowania $\mathrm{z}$ odpadami komunalnymi potraktowane $\mathrm{z}$ należytą uwagą, przepisy są niespójne i trudne w stosowaniu, także dla organów egzekucyjnych. Dlatego należy podkerślić, że ani instrumenty kontrolne, ani egzekucyjne nie zostały skontruowane w sposób spójny i przemyślany. Wydaje się również, że i władze gmin do tej kwestii początkowo nie przywiązywały należytej uwagi - być może wychodząc z założenia, że należy skupić się przede wszystkim na wdrożeniu funkcjonowania nowych systemów. Zauważyć by jednak tu wypadało, że wdrożenie nowych systemów powinno obejmować także działalność uświadamiającą, prowadzoną wobec mieszkańców, ale także szkoleniową dla pracowników aparatu wykonującego te zadania. Wyniki badań wskazują, że ci pracownicy zdają sobie z tego sprawę, jednak bywają w tej mierze pozostawieni sami sobie. Podkreślić w tym kontekście należy fakt, że skuteczna egzekucja pełni także rolę prewencyjną, a więc uświadamiającą; brak zaś czy też nieskuteczność działań egzekucyjnych,w sposób istotny obniżają zaufanie do stanowionego prawa i to w sposób generalny, nie tylko w danej grupie spraw.

\section{BIBLIOGRAFIA}

Bukowski Z., Zadania jednostek samorządu terytorialnego, „Recykling” 2013, nr 12.

Bukowski Z., Prawo gospodarki odpadami, Poznań 2014.

Górski M., Nowy system zarzq̨dzania odpadami komunalnymi?, „Przegląd Komunalny" 2010, nr 12.

Górski M., Odpowiedzialność prawna gmin, „Przegląd Komunalny” 2013, nr 9.

Górski M., Selektywna zbiórka i recykling odpadów po nowemu, „Przegląd Komunalny" 2014, nr 11.

Gruza E., Żebrowska D., Straż Gminna (Miejska). Komentarz do przepisów, Toruń 1996. 
Jerzmański J., Kontrowersje wokót prawnego pojęcia odpadów, „Ochrona środowiska. Prawo i Polityka" 1996, nr 1.

Nowe prawo gospodarki odpadami., red. L. Dubiński, T. Kocoł, Kraków 2013.

Ochendowski E., Prawo administracyjne, Torun 2009.

Prawne i organizacyjne obowiąki gmin $w$ postępowaniu z odpadami komunalnymi, red. M. Górski, K. Nowacki, Wrocław 2012.

Radecki W., Ustawa o odpadach. Komentarz, Warszawa 2013.

Radecki W., Ustawa o utrzymaniu czystości i porzadku w gminach. Komentarz, Warszawa 2012.

Rakoczy B., Utrzymanie czystości i porządku $w$ gminie $w$ prawie polskim, Warszawa 2013.

Wybrane aspekty prawne utrzymania czystości i porzaddku $w$ gminie oraz zadłużenia jednostek samorzadu terytorialnego, red. D. Szafrański, Warszawa 2013.

Kontakt e-mail:

j.kierzkowska@bsw.edu.pl 